\section{Studia z Filologii Polskiej i Słowiańskiej}

DOI: $10.11649 /$ sfps.1924
Studia z Filologii Polskiej i Słowiańskiej, 55

Warszawa 2020

Article No. 1924

Citation:

Глуховцева, К. Д. (2020). Особливості семантичної структури діалектних текстів про важливі історичні події початку XX століття. Studia z Filologii Polskiej i Słowiańskiej, 55, Article 1924. https://doi.org/10.11649/sfps.1924

Hlukhovtseva, K. D. (2020). Osoblyvosti semantychnoï struktury dialektnykh tekstiv pro vazhlyvi istorychni podii pochatku XX stolittia. Studia z Filologii Polskiej i Stowiańskiej, 55, Article 1924. https://doi.org/10.11649/sfps.1924

Катерина Дмитрівна Глуховцева

(Луганський національний університет імені Тараса Шевченка, Старобільськ)

\title{
Особливості семантичної структури діалектних текстів про важливі історичні події початку XX століття
}

\section{Вступ}

Наразі в науковій літературі функціонує велика кількість визначень тексту, що пов’язане з різними аспектами його розгляду. Текст - «динамічна одиниця, організована в умовах реальної комунікації [...], що має екстра- й інтралінгвістичні параметри» (Валгина, 2003, с. 70), - у дискурсології розглядають як письмову фіксацію дискурсу або іншого витвору мовлення; «елемент розширеної бази мовної свідомості»; у комунікативній лінгвістиці - «результат спілкування (комунікації), його структурно-мовний складник та одночасно реалізацію; структуру, у яку втілено дискурс після його завершення»; у загальносеміотичному значенні - як «будьяку організовану сукупність знаків, що розгортається в часі і просторі» (Загнітко, 2012, т. 4, с. 17).

This is an Open Access article distributed under the terms of the Creative Commons Attribution 3.0 PL License (creativecommons.org/licenses/by/3.0/pl/), which permits redistribution, commercial and non-commercial, provided that the article is properly cited. (c) The Author(s) 2020.

Publisher: Institute of Slavic Studies, Polish Academy of Sciences

[Wydawca: Instytut Slawistyki Polskiej Akademii Nauk] 
Поряд із поняттям текст функціонує поняття дискурс, яке нерідко характеризують як загальнонаукову (Павличко, 1999), розмиту категорію (Бацевич, 2002, с. 30), багатовимірне явище (Арутюнова, 1998), когерентний текст (Беллерт, 1978). Лінгвісти його потрактовують у межах кількох глобальних підходів і визначають через поняття текст чи терміни комунікативної лінгвістики або теорії мовленнєвих актів (Голубовська \& Корольов, 2011, сс. 174-180). Виходячи з позицій текстоцентризму, враховуючи погляди вчених на діалектний текст, тлумачать діалектний дискурс Н. В. Гуйванюк і Н. О. Руснак. Вони стверджують, що ці поняття перебувають в ієрархічній залежності, пов'язані відношеннями включення: діалектний дискурс - «це текст, який розглядають з урахуванням комунікативної ситуації» (Гуйванюк \& Руснак, 2015, с. 125). У такому разі дефініція діалектного дискурсу має спільні риси з визначенням, поданим Т. А. ван Дейком і В. Кінчем, згідно з якими дискурс -

складне комунікативне явище, що включає, крім тексту, ще й екстралінгвальні чинники (знання про світ, думки, настанови, цілі адресата), необхідні для розуміння тексту [...] Мовленнєвий потік, мова в її постійному русі, що вбирає в себе всю різноманітність історичної епохи, індивідуальних і соціальних особливостей і комунікатора, і комунікативної ситуації, у якій проходить спілкування (ван Дейк \& Кинч, 1989, сс. 48-49).

Важливість текстоцентричного принципу для діалектологічних досліджень ні в кого не викликає сумнівів, що спонукає науковців при з'ясуванні сутності діалектного тексту передусім звертати увагу на його евристичний потенціал. Так, П. Ю. Гриценко вважає, що діалектні тексти «репрезентують реальне буття мови, склад, функції мовних одиниць, динаміку їх форми і змісту; це реальність мови, не затиснена і не обмежена вузькими берегами нормативних приписів і обмежень, як у літературному різновиді мови» (Гриценко, 2003, сc. XV-XVI). У діалектному тексті відбито реальне співвідношення елементів говіркової структури, що вступають у незвичні, досі не фіксовані синтагматичні зв'язки (Гриценко, 1996, с. 8), це дозволяє реалізувати вичерпний опис українських говірок за певними мовними рівнями (Руснак, 2009, с. 8).

Проте все частіше науковці звертають увагу на багатовимірність діалектного тексту, виділяючи, зокрема, такі ознаки, як когнітивна основа, носій інформації певного типу, усна форма вияву, миттєва вербалізація свідомості, прагматизм, зв’язок з діалектним дискурсом тощо. Такий погляд на названий феномен репрезентований у дослідженнях 
Н. О. Руснак, яка сутність аналізованої одиниці розуміє так: «Це знакове утворення, що має когнітивно-прагматичну основу, це ретранслятор певного типу інформації (Руснак, 2009, с. 396). Н. В. Гуйванюк разом з Н. О. Руснак, доповнюючи це визначення, стверджують, що діалектний текст - це миттєва вербалізація свідомості у формі мовної семіотичної одиниці, що «відповідає прагматичній настанові комунікації» (Гуйванюк \& Руснак, 2015, с. 120), є носієм культурної інформації. Невипадково на основі діалектних текстів наразі вивчають ментальні риси діалектоносіїв (Бігусяк, 2015; Глуховцева, 2015; Колесников, 2015), генезу мікросоціуму (Фроляк, 2013, сс. 93-107), склад населення (Rieger, 2017, с. 9), їхню культурну та мовну ідентифікацію (Глуховцева, 2017), соціокультурні орієнтири тощо.

Помічено, що в багатьох працях поняття текст визначають як один із виявів дискурсу (Бехта, 2004, с. 193), іноді терміни текст і дискурс вважають синонімійними, взаємозамінними (Макаров, 2003, сс. 75-87) чи когерентними: дискурс - «текст плюс ситуація», а текст, відповідно, «дискурс мінус ситуація» (Östman \& Virtanen, 1995, с. 240).

Н. О. Руснак тлумачить текст як живе діалектне мовлення, котре відповідає комунікативній меті, згідно з якою воно створене (Руснак, 2009, с. 27), це живе діалектне мовлення, породжене дією одиничного мовленнєвого акту (Руснак, 2009, с. 28), це діалектний, розмовний, побутовий, неінституційний, особистісно зорієнтований дискурс (Гуйванюк \& Руснак, 2015, с. 126). Підсумовуючи сказане, Н. I. Гуйванюк та Н. О. Руснак знову репрезентують цей феномен, констатуючи, що діалектний текст - це діалектний дискурс, який функціонує в певних ситуативних (комунікативних) умовах, що й зумовлюють його структурно-граматичну організацію (Гуйванюк \& Руснак, 2015, с. 126). Отже, поняття діалектний текст і діалектний дискурс у їхніх працях взаємопов'язані й взаємозумовлені.

Мету цієї статті вбачаємо в тому, щоб проаналізувати семантичну структуру українських східнослобожанських діалектних текстів про важливі соціальні події початку ХХ століття, виявити особливості їхньої мовної репрезентації та динамічні частини формування смислу. Аналізований матеріал добуто шляхом польових записів від респондентів старшої вікової категорії впродовж 1990-2018 років на терені українських східнослобожанських говірок, тобто крайньому сході України (за сучасним адміністративним поділом - у Луганській області). 
Методи дослідження та його науковий апарат. Під час опису свідчень діалектоносіїв використано зіставний та дескриптивний методи, прийоми внутрішньої інтерпретації явищ.

У статті оперуємо термінами текстема - текст, актуалізованими Н. В. Гуйванюк та Н. О. Руснак і розтлумаченими як єдність абстрактного і конкретного при потребі позначення дихотомії на текстовому рівні (Гуйванюк \& Руснак, 2015, с. 124). Відомо, що термін текстема вживають на позначення моделі певного класу текстів, «що охоплює ієрархічно організовані прототипні ознаки певного класу: семіотичні, структурні, інтенційні, прагматичні та інші» (Загнітко, 2012, т. 4, с. 21). $€$. Бартмінський стверджує, що текстема $€$ «абстрактним текстовим зразком», «надіндивідуальним, потенційно існуючим», «який в індивідуальному використанні (у висловлюваннях, у ряді висловлювань, що складають дискурс) може бути (як синтаксичні схеми) наповнений лексичним матеріалом різного ступеня стійкості» (Bartmiński, 1998, с. 18). А. В. Фефілов кваліфікує текстему як концептуально-когнітивну структуру тексту (Фефилов, 2011, сс. 13-23).

У статті визначаємо семантичну структуру аналізованих текстів, ураховуючи положення $Є$. Бартмінського, який при визначенні тексту використовує поняття макрознак, обгрунтовує думку про структурні особливості цієї складної мовної одиниці: «Текст - це надфразна мовна одиниця, макрознак, який має певні жанрові та стилістичні ознаки (кваліфікатори тексту), підлягає цілісній семантичній та комунікативній інтерпретації, відзначається структурною інтегрованістю й тематичною зв'язністю, дозволяє внутрішнє семантичне членування, а у випадку розлогих текстів - логічне та композиційне» (Бартминьский, 2005, с. 290).

Під семантичною структурою тексту розуміємо єдність теми і мікротем, що виражена «наявними в тексті номінаціями» процесів, денотатів, пов’язаних у цілісний семантичний комплекс, який $є$ моделлю ситуації, що реалізована мовними засобами цього тексту (Новиков, 1983, с. 117).

Оперуємо також поняттям макротекст, під яким розуміємо «сукупність висловлювань чи текстів, об'єднаних за змістом або ситуативно, а також пов'язаних на основі структурно-композиційних і культурних ознак. Це цілісне утворення, єдність якого грунтується на тематичній спільності одиниць, що в нього входять (мікротекстів)» (Данилевская, 2003). 


\section{Результати дослідження}

До основних ознак тексту (текстових категорій) відносять передусім інформаційну і структурну єдність, комунікативність, функціональну завершеність, цілісність і зв’язність, зокрема й семантичну, що забезпечується єдністю теми і мікротем (Селіванова, 2006, сс. 601-602). У діалектних текстах про важливі історичні події ХХ століття відображено онтологічний (буттєвий) і гносеологічний (пізнавальний) аспекти проблем, порушених у висловлюваннях. Важливими також є власне лінгвістичний (вербальне вираження об’єкта), психологічний та прагматичний (спрямування на реалізацію наміру автора).

Семантична структура уснорозмовних текстів-спогадів про важливі історичні події першої половини ХХ століття маніфестована концептоблоками, що характеризуються логіко-семантичними ознаками процесуальності, акціональності, темпоральності, агентивності, денотативності, оцінності. Це найменування самих явищ та назви сукупності денотатів, що пов’язані предметними відношеннями у цілісний семантичний комплекс, номінативний ланцюг, який репрезентує семантичну сітку тексту. У наративних текстах про колективізацію одиницями реального ядерного простору тексту є зга' в кол'хози, колєктіві'зація, в оповідях про розкуркулювання - розку'лачування, розку'лачувати, у спогадах про голодомор - голодовка, голодо'мор, 'голод.

Умовно при семантичному аналізі текстів будь-якої з названих тем можна виділити текстеми, тобто моделі семантичної структури тексту, кожна з яких має смислові диференційні риси, виділені на основі семантичного членування тексту. Обов'язковими смисловими компонентами текстеми колективізація є назви самого явища. Якщо проаналізувати тлумачення лексеми колгосn, подане в кодифікованих загальномовних словниках:

колективне господарство (соціалістична форма виробничого об'єднання трудящих селян для колективного ведення сільського виробництва) (ВТССУМ, 2005, c. 553);

скорочення: колективне господарство (соціалістична форма виробничого об’єднання трудящих селян для колективного ведення сільського господарства, що грунтується на усуспільненні основних засобів виробництва) (СУМ, 1970-1980, т. 4, с. 216),

то «усуспільнення основних засобів виробництва» мало б проходити добровільно. Проте свідчення очевидців переконують, що забирали 
майно при утворенні колективних господарств силоміць або під тиском керівних органів. У цьому разі тексти рясніють перерахуванням назв худоби, птиці, домашнього начиння, яке відбиралося:

Позда' вали ху'добу у кол'хоз / ' $^{\prime}$ кого шо бу бо / хто ко'ня / хто ко'рову / хто во лів (Записано від Четверик К. О., 1919 р. н., с. Шульгинка, Старобільський р-н)';

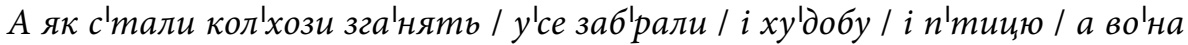
'бідна pe'ве / го'лодна / (Записано від Смалька М. Д., 1909 р. н., с. Нижня Дуванка, Сватівський р-н);

Се'ляни з'возили сво'їх ко'ней / во'лів / плу'ги дав'али / б'рички да'вали / у'се одда'вали у кол'госпи / от і пращю'вали у кол'госпах (Записано від Неброя Ф. Ф., 1927 р. н., с. Донцівка, Новопсковський р-н).

С. В. Волошина, вивчаючи особливості автобіографічних розповідей у діалектній комунікації, констатує, що респондент намагається «презентувати розповідь за короткий проміжок часу і без тривалих роздумів», що сприяє актуалізації найбільш важливих для нього життєвих фактів (Волошина, 2008, с. 11). У текстах про історичні події початку ХХ століття виявлено ту саму прагматичну настанову мовця. Тому основне смислове навантаження в розповідях про колективізацію припадає на іменники та дієслова, які виконують у спогадах текстотворчу функцію.

Імпліцитність чи експліцитність характерна для фрагментів текстів, у яких указано рік створення колгоспу, завдяки чому вербалізується чи не вербалізується темпоральність:

От'куда піш'ли ці п'розвища / я не з'наю / ще бу ло дав'но / ко'ли бу'ла колективі заиія (Записано від Войтенка М. Й, 1911 р. н., с. Чмирівка, Старобільський р-н);

Колективі'зація бу'ла десь у д'вадияльь вось'мом го'ду / а я то'ді ще ма'ла бу'ла / не 'помню ї̈ (Записано від Скнариної Г. І., 1918 р. н., с. Ганусівка, Новопсковський $\mathrm{p}-\mathrm{H})$.

Не в усіх текстах названо людей, які брали участь у розкуркулюванні чи колективізації (отже, представлено чи не представлено агентивність):

Хторовку'лачував ? та я йо'го не 'хочу ка'зать / бо 'їхні 'родичі й 'досі тут жи'вуть (Записано від Кошель Д. О., 1917 р. н., с. Верхня Дуванка, Сватівський р-н);

1 Тут і далі наводимо приклади текстів, записані звичайною графікою із збереженням уснорозмовних явищ (Луганська область, Україна). 
Г'ришка Кірі'ченко був прідсі'дателем / хо'дили по се'лу / про'сили і'ти в кол'хоз // ну хто хо'тіли / піш'ли // а ба'гато не хо'тіли / так ті зда'вали ко'ров та 'коней / а ще хто не хо'тів / тих усе прода'вали / ви'возили на яр'ки // а ще був ак'тів / тру'сили му'ку та пше'нииу // так о'то як n'ройдуть / так і пау'тину позаби'рають // ку'ма 'Дунька 'тоже в а'ктіві бу'ла // заро'била йа ко лись на 'затірку му'ки / а во'на прийш'ла і заб'рала // а ще об'йіжчик Ан'тон Я'ружній був / так той га'няв з бато'жарою по ' полю // ну/ о'то ота'ка жизнь у нас бу'ла (Записано від Василенко А. О., 1919 р. н., с. Білолуцьк, Новопсковський р-н).

Приховування прізвищ тих активістів, які брали участь у розкуркулюванні, колективізації, свідчить про те, що селяни й досі бояться говорити правду, часто просто уникають розмов на такі теми. $Є$ розповіді, у яких активістів схарактеризовано загалом, без називання прізвищ - комі'тетчики; 'люди з 'нашого сел'а; 'люди 'бідні і беззе 'мельні; 'n'яниці; леда'рюги:

Жи'ли ми то'ді 'тільки за ра'хунок сво'єї п'ращі // у ха'зяйстві бу'ли 'пара 'коней $i$ 'пара волів // ми то'ді жи'ли індівіду'ально // тік був с'пілним / ним користу'валися всі // ще і до сих пір у декого під дво'ром ле жать шестиг'ранні вал'ки / 'витесані з 'дикого 'каменю / я'кими моло'тили пше'ницю і я'кі тя'гала по то'ку 'пара 'коней // а'ле ось прий'чов перево'рот // ие по'том $y^{\prime}$ же с'тали нази'вать жовт' невою рево'люцією // і ось то ді появи'лися комі'тетчики // ие бу ли 'люди з 'нашого сел' / я'кі жи'ли на од'ній 'вулиці з 'нами // в основ'ном ие бу'ли 'люди 'бідні і беззе'мельні // а'ле най'більше в ці комі'тети піш'ли 'n'янииі / леда'рюги / я'кі ні'коли на зем'лі ні'чого 'путнього не ро'били $і$ за ско'тиною ні'коли не ходили // і от як да'ли їм власть і на'гани / то во'ни поча'ли / як то'ді ка'зали / розку'лачувати // нача'ли з 'того / шо прийщ'ли до нас $y^{\prime}$ хату / одк'рили ск'риню і заб'рали 'наші с'витки й ко'жухи та дру'гі 'вєщі // по'том пооді'вали усе ие на 'себе і поначіп'ляли з'верху чер'воні бан'ти іна'гани // по'том позаби'рали 'коней і волтів і поодво'дили у кол'госп / а так як у кол'госпі то'ді бу'ли та'кі ж хазяй'ни / як і комі'тетчики / то за 'зіму ба'гато ско'тини похво'рілося і попропа'дало / а ці но'ві хазяй'ни по'бачили / шо наро'били 'лиха / та й повті'кали до' Лу'ганська на за'води i' фабрики / ба'гато лю'дей не хо'тіло йти до кол'госпу / а хо'тіли жити й працю'вати для 'себе та сво'єї сі'м'ї / але їх пос'тавили в та'ке ста' новище / шо вони $3^{\prime}$ мушені бу'ли пі'ти на ро'боту в кол'госп (Записано від Недовєсової У. С., 1915 р. н., с. Донцівка, Новопсковський р-н).

У тексті можна виділити фрази, завдяки яким протиставлено індивідуальний спосіб господарювання та, пізніший, колективний:

з одного боку -

жи'ли за ра'хунок сво'єё п'раці; 
жи'ли індівіду'ально;

ним користу'валися всі (током);

3 іншого -

почали розку'лачувати; заб'рали 'наші с'витки й ко'нухи та дру'гі 'вєщі; позаби'рали 'коней і во лів;

поодводили у колгосп; за 'зіму ба'гато ско'тини похво'рілося і попропа'дало; ба'гато лю'дей не хо'тіло йти до кол'госпу; хо'тіли жити й працю' вати для 'себе та сво'єї сі'м' $\ddot{\imath} ;$

їх пос'тавили в та'ке ста'новище / шо вони з'мушені бу ${ }^{\prime}$ ли пі'ти на ро'боту в кол'госп.

Вербально невираженими іноді $€$ також компоненти, у яких констатовано, що вести колективне господарство було складно, а отже, активісти, після того, як зимою худоба була майже вся знищена, повтікали з села, повлаштовувалися на роботу десь у місті.

Отже, текстема колективізація має такі смислові диференційні риси:

'вказівка на час, коли проходило утворення колгоспів';

'називання осіб, які забирали майно селян у колгоспи';

'перерахування майна, худоби, які треба було здати в колгосп';

'оцінка дій односельчан, які займалися утворенням колгоспів';

'характеристика особливостей господарювання в новостворених господарствах'.

Макротекст, об’єднаний темою колективізація, створений різними респондентами, фіксує такі ментальні риси мовної спільноти ареалу, як бережливе ставлення до майна, нажитого важкою щоденною працею; повага до трударів, які вміють господарювати; засудження лінощів, людей, які хочуть заволодіти плодами чужої праці; неприйняття насилля. Різняться уснорозмовні тексти також ступенем деталізації переказаних подій, що відкриває можливості для вивчення мовленнєвих прагматичних інтенцій діалектоносія як мовної особистості.

Текстема розкуркулювання має спільні смислові диференційні риси з текстемою колективізація, оскільки ці дві події проходили одночасно, тому діалектоносії часто їх поєднують. Семантична сітка наративів на цю тему зазвичай включає: назви майна, яке було вилучено в розкуркулених людей, найменування дій владних осіб, які здійснювали розкуркулювання. 
Зазвичай вербалізовано думку про те, що виселялися з сіл нерідко саме трудолюбиві господарі або ті, що своєю працею нажили майно. Варіантність властива компонентам, у яких розвивалися мікротеми про те, яких лихоліть було завдано розкуркуленим жителям краю. У таких текстах вербально наповненою $€$ аксіональність оповіді:

Жи'ли в 'нашому се'лі три сім'ні Ли'манських // в'ласті рі' шили / шо во'ни ба'гаті чим д'ругі / $i^{\prime}$ вислали дві сім'ні в Ар'хангельськ / а од'ну сі'м'ю за'лишили / бо в них був інва'лід // є тут у нас Про'каза На'талія 'Федоріууна / так родину 'ї̈ чоло'віка у то в вемя розкур'кулили / ку'ди їх 'вислали / я не з'наю / та 'кажеция / шо 'батько йо'го по'мер / а 'мати не дожи'ла три 'місяці до по'вернення (Записано від Войтенка М. Й., 1911 р. н., с. Підгорівка, Старобільський р-н).

Серед назв осіб, які особливо жорстоко поводилися з селянами, у наративах про розкуркулювання виділяємо загальні іменники, рідше займенник (в'ласті, aк'miв, акті'вісти, во'нu). У багатьох висловленнях суб'єкт дії відсутній, а тому основну текстотворчу та семантичну функцію виконують дієслова минулого часу множини як головні члени в неозначено-особових конструкціях ('вислали, ви'возили, забі'рали, застав 'яяли, розку'лачували, вики'дали). Загалом у тих фрагментах текстів, де йдеться про поневіряння людей, експресивність висловлення створена через ампліфікацію - нагромадження однорідних елементів мови, зокрема дієслів, якими респонденти характеризують протиправні дії представників влади:

Д'вадиять де'в'ятий / ие вже нача'лась колектіві'зація / а до д'вадиять де' в'ятого дер'жали з'емлі // а по'том 'начали зга'нять / 'землю застав-

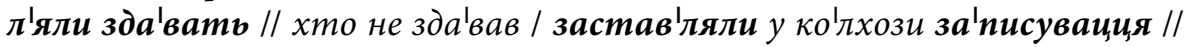
не х'отіли / у кол'хози 'люди ст'рашно не хо'тіли йти // розку'лачували / ви'возили на Солов'ки лю'дей // ви'возили / тут Баба'рицина нази'ваюиияя яр 'ки / ви'возили і вики'дали люд'ей // 'вимерло тут лю'дей 'більще / чим ос'талося // я'кі 'люди змог'ли / поті'кали в Дон'бас / і я 'лічно втекл'а (Записано від Дегтярової О. П., 1915 р. н., сел. Біловодськ).

Тексти цієї тематики насичені мовними засобами вираження експресивних оцінок, які конотують текст, наповнюють семантичну сітку оцінним значенням. Цей період у житті селян респонденти називають тра'гедією ве ликої 'кількості людей / 'часом / коли та'ке тво'рилося. Пейоративної конотації текст набуває завдяки вживанню слів розмовної лексики, зокрема іменників і дієслів: 
Ой / я то'ді / гля'діть / бу'ла ще малу'вата / ну 'помню / як ко'ров забі'рали i $з$ 'довгими о'то 'гострими 'палками хо'дили / y 'землю ши'ряли / щи'тали / шо десь пше'ниия за'хована // а 'батько ка'же / мо ви о'то / х'лопиі / 'ходите / о'ие б ми 'дітей 'голодом мо'рили / ви поди'віиця / он шо нава'рили (Записано від Синельник О. А., 1915 р. н., с. Третьяківка, Біловодський р-н);

Та о'це ж ви бу'ли в 'Кобиевой / о'то ж я'кий чоло'вік / я'кий тру'дяга / я'кі ж бу'ли $\boldsymbol{x}^{\prime}$ лопиі / 'мамка ще жи'ві бу'ли / а в нас о'тут за са'раєм парни'ки / го'родництво бу'ло // о'тож во'ни приї'хали / по'сиділи / i ма'щина пі'д'їхала і о'то // як со'бак повки'дали / 'батька заб'рали 'ноччю в сельсо'вєт (Записано від Чернявської М. Т., 1918 р. н., с. Третьяківка, Біловодський р-н).

Важливу функцію виконують також прислівники (у кол'хози 'люди ст'рашно не хо'тіли йти).

Загалом текстема розкуркулювання маніфестує такі смислові диференційні риси:

'назва часу, коли проходило розкуркулювання';

'називання осіб, які забирали майно селян';

'перерахування майна, худоби, які було вилучено в односельчан';

'називання місця, куди виселяли розкуркулених жителів села';

'характеристика дій активістів'.

Тесктема голодівка має такі структурні та смислові риси:

'перерахування назв трав, бур'янів, якими харчувалися' (лопуцьки їли; кору їли; жолуді, бур'ян, пшінку копали),

'найменування страв, які можна було приготувати без борошна' (пекли коржі з лободи кучерявої; пекли макорженики, ладики, галєти), 'характеристику самої ситуації' ('голодже та'кий був; 'дуже тя'жолий [голод]; 'дуже бу' 'пухлі хо'дили, о-ой, ой!).

Нерідко наративи мають перекази конкретних ситуацій, у які потрапляли самі оповідачі чи їхні знайомі:

Зер'но бу'ло / а з 'голоду вмі'рали / у кол'хозі бу'ло зер'но / а 'людям не да'вали // 'батько мій сте'ріг 'возлє ам'барів // ну і о'дин х'лопець нато'чив зерн'а / ну во'ни не 'бачили / а хтось по'бачив і зая'вив / $і$ їх заб'рали двох / во'ни вдвох жи'ли з од'ним 'дідом // дер'жали їх там шіс'наиять 'суток / по'ка пере'важили усе зер'но в той ко'морі // году'вали там ма'кухою / а 'дідові то'му д'ругому закла'дають в рот револь'вера / і призна'вайся / б'рали ви 
зер'но чі ні (Записано від Неброй В. П., 1927 р. н., с. Донцівка, Новопсковський $\mathrm{p}-\mathrm{H})$.

Деякі респонденти розповідають, що в роки голоду росли якісь гриби, які вони називали гараш'ки, го'ряшки (чі то так Бог дав / чі

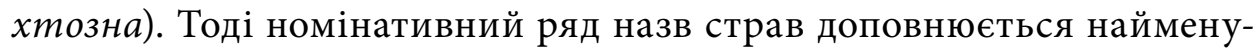
ванням грибів:

Ну в нас корру '̈̈ли / ло'пуцъьки // гараш'ки зби'рали / гри'би та'кі як у'сіяли o'my 'гору // ми вже 'пухлі бу'ли (Записано від Семистяги О. С., 1912 р. н., с. Нижня Дуванка, Сватівський р-н).

Характер поневірянь респонденти передають загальними найменуваннями та перерахуванням конкретних дій, спрямованих на пригнічення селян:

'Голод та'кий був // ро'били 'люди // сна'чала розку'лачування бу'ло / от / кула'ків розку' 'лачували / ви'тягували з хат уяр 'ки ту'ди / от пере'дохли лю'ди / на ходу 'дохли / жил'и на бур'я'ну // о'то бу'р'ян 'бабки та пердунн / шо не 'надо ка' зать / 'рогіж у'тому / у ли'мані / ро'бив иіл'овєк 'задурно / не да' вали ні'чого / ре'мітельно (Записано від Індиченко I. I., 1922 р. н., c. Танюшівка, Новопсковський р-н).

У текстах може варіюватися характер подачі негативної оцінки ситуації та дій владних структур. Одні респонденти звинувачують у всьому місцевих керівників, інші - центральні органи влади:

Ох // ие все C'талін ро'бив / гад / 'деспот / 'руський ду'рак наз'начив гру'зіна Жугаш'вілі / наз'начив гос' подствувать от о чим госу'дарством / от / ну й шо ж / то'ді пот'рошку с'тали / i m'oді він із'дох / став по'рядок / от // дісиіп'ліна / с'тали вже в кол'хозі да'вать // у мага'зінах усьо'го хва'тало / так шо вже 'можна жить (Записано від Індиченко I. I., 1922 р. н., с. Танюшівка, Новопсковський р-н);

Ота'ка пше'ниия сто'яла в нас / і ота'кі ве ликі ко лосся / а ніз зя бу ло взять // лю'ди 'пухли i 'мерли / а ніль'зя колос'ка бу'ло взять / i ми / 'помню / як нес'ли б'ратіка хоро'нити // у та'кий квіт частий пла'ток тру'на об'горнута // o'mо нес'ла сест'ра / а 'мама йшли / n'лакали / а ото'го зер'на / во'но так 'пахло ме'ні / шоб з'їсти // а ніз'зя // 'мама 'кажуть / не хо'ди / 'доцю // [...] а той хам / гла'дючий о'то 'морда / i о'то нільз'зя колос'ка 'вирвать // а як він ме'ні пах // я ще й 'зараз ощу'щзаю // а о'то 'бабу 'Дуньку / ну цее вже в 'сорок 'свомому го'ду бу'ло // во'на принес'ла кілог'рам чі два буря'ків / так її посафдли на сім годів у тюр'мі (Записано від Соболь М. О., 1919 р. н., с. Верхня Дуванка, Сватівський р-н). 
Розлогими є сюжети про смерть знайомих, сусідів, односельців:

Бу'ло ус'танеш 'утром / хто-'небудь із су'сідів 'коло х'ати ле'жить / у'мер / Да'нило / су'сід наш / 'сили не бу'ло про'сити / так він умер // ота'ке бу'ло (Записано від Тарасової М. Т., 1919 р. н., с. Великоцьк, Міловський р-н);

розповіді про благочинність, взаємодопомогу:

Так як ми жи'ли неда'леко од вок'залу / а то'ді ' поїз хо'див / ку'куика нази'вався // [...] от откри'ваюиия д'вері / за'ходе / з 'поїзда йдуть і п'росять / пересту'nа nо'ріг / 'nадає на ко'ліна / сам страш'ний / от / i з'разу 'падає на ко'ліна n'росе шо-не'будь / і уми'рає з го'лоду / 'бабушка оце 'піде / завж'ди i'буряк / $i^{\prime}$ морква / кар'тошка / завж'ди на'варене бу'ло // та'кого ж там борш приготу'вати чи суп приго'тувати / не хва'тало / та ще та'ка сі'м'я / 'бабушка / ну шо ж я то'бі дам / як ме'ні жско'̈̈м шо да'вати? // не з'наю / не у'терпе / ви'носе / дає (Записано від Король Т. Н., 1917 р. н., с. Микільське, Міловський р-н).

Периферійними в текстах про голод можна назвати оповіді, у яких мова йде про випадки канібалізму, намагання заволодіти чужим майном, щоб потім за нього придбати продукти, оповіді про те, як люди не витримували тяжкого голоду:

За'різали ко'рову / 'мясо пос'тавили у г'рубу // 'голод невино'сімий // 'мясо пос'тавили у г'рубу / шоб на 'ранок же 'мясо бу'ло [...] і во'но ус'тало / те ди'тя / чаву'на розк'рило / 'витягло 'кістку з 'мясом і гри'зе // а 'мати ж 'чує / шо шось п'лямка / та як схватилась! // а во'но си'діло 'коло г'руби і гри'зе 'мясо // 'вихватила ту 'кістку із ру'ки і по голо'ві // на 'ранок усі з'нали / шо По'тончиха у'била сво'ю ди'тину (Записано від Мєдвєдєва I. І., 1923 р. н., с. Морозівка, Міловський р-н).

Загалом текстема голодівка репрезентована центральними смисловими диференційними рисами:

'перерахування рослин, які можна було використовувати в їжу';

'назви страв, які можна було приготувати без муки';

'загальна оцінка ситуації; 'перерахування незгод, які довелося пережити людям';

'номінація способів виживання людей у важких умовах';

'як хоронили померлих'

і периферійними

'хто призвів країну до голоду'. 
У текстах можуть варіюватися компоненти про випадки канібалізму, заволодіння чужим майном, звинувачення на адресу конкретних людей, які відбирали в односельчан їжу, стежили за тим, щоб із колгоспу ніхто нічого не взяв тощо.

Загалом розповіді-спогади про історичні події початку XX століття важливо вивчати, зважаючи на гносеологічне значення інформації, яка в них закладена. Ці пам'ятки історії репрезентують ставлення мовців, жителів крайнього сходу України до подій столітньої давнини, свідчать про їхні соціальні орієнтири. Респонденти засуджують насильницьке утворення колгоспів, розкуркулювання, коли було знищено багато жителів краю, відчуження селян від землі, господарювання на ній. Голодівку 1933 року називають одним із способів нищення українського народу. Оцінка історичних подій XX століття пересічними жителями краю та й усієї України важлива для встановлення історичної справедливості, виявлення ментальних рис населення краю, розуміння того, яких жертв коштували перетворення названого часу.

\section{Висновки}

Текст як цілісне семантичне утворення може членуватися на мікротеми, що дозволяє виділити ядерні та периферійні концептоблоки. Ядро зазвичай складають номінації, задані темою. Семантичну сітку тексту доповнюють найменування, пов’язані з мікротемами, що розвинені в тексті. Аналіз кількох (чи багатьох) текстів однієї тематики дозволяє виділити текстему, тобто семантичну модель тексту. У змістовій структурі текстеми про історичні події початку XX століття можна виділити центральні й периферійні диференційні риси. Скажімо, центральною диференційною рисою текстеми колективізація $\epsilon$ репрезентація найменування самого явища (зга'няти в кол'госпи), накопичення назв худоби, домашнього начиння, майна, яке добровільно здавалося в колгосп чи вилучалося, якщо селяни чинили спротив; маніфестація номінацій негативної оцінки дій односельчан, які займалися утворенням колгоспів. Периферійними $є$ риси, у яких вербалізовано час, коли проходило утворення колгоспів; представлено характеристику особливостей господарювання в новостворених господарствах. При називанні осіб, які забирали майно селян у колгоспи, респонденти нерідко вдаються до загальних назв, уникають перерахування конкретних осіб, які здійснювали колективізацію, що свідчить про імпліцитний характер таких спогадів. 
Тексти-спогади, оповіді, що містять оцінку важливих суспільних подій початку XX століття діалектоносіями Луганщини, становлять один макротекст, у якому засуджуються злочини, зроблені проти простого народу - виселення хліборобів до Сибіру, примусова колективізація, голодомор 1933 року, відчуження від усього українського. Основними засобами вербалізації оцінки цих подій у текстах $є$ вигуки, слова з яскравою емоційною оцінкою.

Перспективи цього дослідження вбачаємо в тому, щоб проаналізувати семантичну структуру текстів про історичні події першої половини $\mathrm{XX}$ століття на ширшому ареалі та виявити локально вживані номінації в уснорозмовних оповідях респондентів.

\section{Скорочення}

ВТССУМ - Великий тлумачний словник сучасної української мови, 2005.

СУМ - Словник української мови, 1970-1980.

\section{Бібліографія}

Арутюнова, Н. Д. (1998). Язык и мир человека. Языки русской культуры.

Бартминьский, Е. (2005). Языковой образ мира: Очерки по этнолингвистике. Индрик.

Бацевич, Ф. (2002). Термінологія комунікативної лінгвістики: Аспекти дискурсивного підходу. Вісник Національного університету “Львівська політехніка”, 2002(453), 30-34.

Беллерт, М. (1978). Об одном условии связности текста. Новое в зарубежной лингвистике, 1978(8), 172-207.

Бехта, I. А. (2004). Дискурс наратора в англомовній художній прозі. Грамота.

Бігусяк, М. В. (2015). Тексти як джерело дослідження говірок Івано-Франківщини: історіографія та перспективи розвитку. In П. Ю. Гриценко (Ed.), Діалекти в синхронії та діахроніі: Текст як джерело лінгвістичних студій (рp. 17-29). Видавництво ТОВ “КММ”.

Валгина, Н. С. (2003). Теория текста. Логос.

ван Дейк, Т. А., \& Кинч, В. (1989). Макростратегии (В. И. Герасимов, Trans.). In Т. А. ван Дейк, Язык: Познание: Коммуникация (рр. 41-67). Прогресс.

Великий тлумачний словник сучасної української мови [ВТССУМ]. (2005). ВТФ “Перун”.

Волошина, С. В. (2008). Автобиографический рассказ как объект лингвистического исследования. Вестник Томского государственного университета, 2008(308), 11-15. 
Глуховцева, К. Д. (2015). Ментальність діалектоносія та особливості діалектного дискурсу. In П. Ю. Гриценко (Еd.), Діалекти в синхронї та діахронії: Текст як джерело лінгвістичних студій (pp. 75-82). Видавництво ТОВ “КММ”.

Глуховцева, К. Д. (2017). Соціокультурна, етнічна та мовна самоідентифікація діалектоносіїв Луганщини. Волинь-Житомирщзина: Історико-фолологічний збірник з регіональних проблем, 2017(28), 16-23.

Голубовська, І. О., \& Корольов, І. Р. (2011). Актуальні проблеми сучасної лінгвістики: Курс лекцій. Київський університет.

Гриценко, П. Ю. (1996). Тексти як джерело дослідження чорнобильських говірок. In П. Ю. Гриценко (Ed.), Говірки Чорнобильської зони: Тексти (pp. 7-19). Довіра.

Гриценко, П. Ю. (2003). Тексти як джерело дослідження українських говірок Румунії. In М. Павлюк \& I. Робчук, Українські говори Румунії: Діялектні тексти 1 (pp. I-XVI). Інститут українознавства ім. І. Крип'якевича НАН України.

Гуйванюк, Н. В., \& Руснак, Н. О. (2015). Багатовимірна реальність діалектного тексту. In П. Ю. Гриценко (Ed.), Діалекти в синхронії та діахронії: Текст як джерело лінгвістичних студій (рp. 119-127). Видавництво ТОВ "КММ".

Данилевская, Н. В. (2003). Макротекст. In Стилистический энциклопедический словарь русского языка. Наука; Искусство.

Загнітко, А. П. (2012). Словник сучасної лінгвістики: Поняття і терміни: У 4 томах (Vols. 1-4). ДонНУ.

Колесников, А. О. (2015). Морфологія українських південнобессарабських говірок: Генеза і динаміка. СМИЛ.

Макаров, Л. М. (2003). Основы теории дискурса. Гнозис.

Новиков, А. И. (1983). Семантика текста и ее формализация. Наука.

Павличко, С. (1999). Дискурс модернізму в украӥнській літературі: Монограбія. Либідь.

Руснак, Н. О. (2009). Діалектний текст: Лінгвокогнітивний та прагматичний аспекти дослідження. Чернівецький національний університет.

Селіванова, О. (2006). Сучасна лінгвістика: Термінологічна енциклопедія. Довкілля.

Словник украӥнської мови: В 11 томах [СУМ]. (1970-1980). Наукова думка.

Фефилов, А. И. (2011). Текстема (энциклопедическая). Мир лингвистики и коммуникации: Электронный научный журнал, 1(23), 13-23.

Фроляк, Л. Д. (2013). Українські східностепові говірки Донеччини: Монограбія. Поствіт.

Bartmiński, J. (1998). Tekst jako przedmiot tekstologii lingwistycznej. In J. Bartmiński \& B. Boniecka (Eds.), Tekst: Problemy teoretyczne (pp. 9-25). Wydawnictwo Uniwersytetu Marii Curie-Skłodowskiej.

Östman, J.-O., \& Virtanen, T. (1995). Discourse analysis. In J. Verschueren, J.-O. Östman, \& J. Blommaert (Eds.), Handbook of pragmatics (pp. 239-253). John Benjamins Publishing Company. https://doi.org/10.1075/hop.m.dis1 
Rieger, J. (2017). Atlas ukraińskich gwar nadsańskich (Vol. 1). Wydział “Artes Liberales" (Uniwersytet Warszawski).

\section{Bibliography (transliteration)}

Arutiunova, N. D. (1998). IAzyk i mir cheloveka. IAzyki russkoĭ kul'tury.

Bartmin'skiŭ, E. (2005). IAzykovoĭ obraz mira: Ocherki po ètnolingvistike. Indrik.

Bartmiński, J. (1998). Tekst jako przedmiot tekstologii lingwistycznej. In J. Bartmiński \& B. Boniecka (Eds.), Tekst: Problemy teoretyczne (pp. 9-25). Wydawnictwo Uniwersytetu Marii Curie-Skłodowskiej.

Batsevych, F. (2002). Terminolohiia komunikatyvnoï linhvistyky: Aspekty dyskursyvnoho pidkhodu. Visnyk Natsional'noho universytetu "L'vivs'ka politekhnika", 2002(453), 30-34.

Bekhta, I. A. (2004). Dyskurs naratora v anhlomovniŭ khudozhniı̌ prozi. Hramota.

Bellert, M. (1978). Ob odnom uslovii sviaznosti teksta. Novoe v zarubezhnoŭ lingvistike, 1978(8), 172-207.

Bihusiak, M. V. (2015). Teksty iak dzherelo doslidzhennia hovirok Ivano-Frankivshchyny: Istoriohrafiia ta perspektyvy rozvytku. In P. I. Hrytsenko (Ed.), Dialekty v synkhronii ta diakhronii: Tekst iak dzherelo linhvistychnykh studiu (pp. 17-29). Vydavnytstvo TOV "KMM".

Danilevskaia, N. V. (2003). Makrotekst. In Stilisticheskiŭ éntsiklopedicheskiŭ slovar' russkogo iazyka. Nauka; Iskusstvo.

Fefilov, A. I. (2011). Tekstema (èntsiklopedicheskaia). Mir lingvistiki i kommunikatsii: Ėlektronnyı̆ nauchnyi zhurnal, 1(23), 13-23.

Froliak, L. D. (2013). Ukraïns'ki skhidnostepovi hovirky Donechchyny: Monohrafiia. Postvit.

Hlukhovtseva, K. D. (2015). Mental'nist' dialektonosiia ta osoblyvosti dialektnoho dyskursu. In P. I. Hrytsenko (Ed.), Dialekty v synkhronii ta diakhroniï: Tekst iak dzherelo linhvistychnykh studiu (pp. 75-82). Vydavnytstvo TOV "KMM".

Hlukhovtseva, K. D. (2017). Sotsiokul'turna, etnichna ta movna samoidentyfikatsiia dialektonosiïv Luhanshchyny. Volyn'-ZHytomyrshchyna: Istoryko-filolohichnyı zbirnyk z rehional'nykh problem, 2017(28), 16-23.

Holubovs'ka, I. O., \& Korol'ov, I. R. (2011). Aktual'ni problemy suchasnoï linhvistyky: Kurs lektsiǔ. Kyïvs'kyĭ universytet.

Hrytsenko, P. I. (1996). Teksty iak dzherelo doslidzhennia chornobyl's'kykh hovirok. In P. I. Hrytsenko (Ed.), Hovirky Chornobyl's'koï zony: Teksty (pp. 7-19). Dovira.

Hrytsenko, P. I. (2003). Teksty iak dzherelo doslidzhennia ukraïns'kykh hovirok Rumuniï. In M. Pavliuk \& I. Robchuk, Ukraïns'ki hovory Rumunii: Dialektni teksty 1 (pp. I-XVI). Instytut ukraïnoznavstva im. I. Kryp'iakevycha NAN Ukraïny.

Huǐvaniuk, N. V., \& Rusnak, N. O. (2015). Bahatovymirna real'nist' dialektnoho tekstu. In P. I. Hrytsenko (Ed.), Dialekty v synkhronii ta diakhronii: Tekst iak dzherelo linhvistychnykh studiu (pp. 119-127). Vydavnytstvo TOV “KMM". 
Kolesnykov, A. O. (2015). Morfolohiia ukrä̈n'kykh pivdennobessarabs'kykh hovirok: Geneza i dynamika. SMYL.

Makarov, L. M. (2003). Osnovy teorii diskursa. Gnozis.

Novikov, A. I. (1983). Semantika teksta i ee formalizatsiia. Nauka.

Östman, J.-O., \& Virtanen, T. (1995). Discourse analysis. In J. Verschueren, J.-O. Östman, \& J. Blommaert (Eds.), Handbook of pragmatics (pp. 239-253). John Benjamins Publishing Company. https://doi.org/10.1075/hop.m.dis1

Pavlychko, S. (1999). Dyskurs modernizmu v ukrä̈n'kiŭ literaturi: Monohrafiia. Lybid'.

Rieger, J. (2017). Atlas ukraińskich gwar nadsańskich (Vol. 1). Wydział “Artes Liberales” (Uniwersytet Warszawski).

Rusnak, N. O. (2009). Dialektnyĭ tekst: Linhvokohnityvnyĭ ta prahmatychnyı̆ aspekty doslidzhennia. Chernivets'kyı̆ natsional'nyı̆ universytet.

Selivanova, O. (2006). Suchasna linhvistyka: Terminolohichna entsyklopediia. Dovkillia.

Slovnyk ukraïns'koï movy: V 11 tomakh [SUM]. (1970-1980). Naukova dumka.

Valgina, N. S. (2003). Teoriia teksta. Logos.

van Deı̆k, T. A., \& Kinch, V. (1989). Makrostrategii (V. I. Gerasimov, Trans.). In T. A. van Deǐk, IAzyk: Poznanie: Kommunikatsiia (pp. 41-67). Progress.

Velykyĭ tlumachnyi slovnyk suchasnoï ukraïns'koï movy [VTSSUM]. (2005). VTF "Perun”.

Voloshina, S. V. (2008). Avtobiograficheskiǔ rasskaz kak ob"ekt lingvisticheskogo issledovaniia. Vestnik Tomskogo gosudarstvennogo universiteta, 2008(308), 11-15.

Zahnitko, A. P. (2012). Slovnyk suchasnoï linhvistyky: Poniattia i terminy: U 4 tomakh (Vols. 1-4). DonNU.

\section{Features of Semantic Structure of Dialectal Texts Concerning Important Historical Events of the Early Twentieth Century}

\section{Summary}

This article analyses the semantic structure of dialectal texts concerning important historical events of the early twentieth century, describes the characteristics of their linguistic representation and presents dynamic aspects of sense formation. The analysed material comes from the older generation of 
respondents interviewed in the course of fieldwork conducted in 1990-2018 in the area of Ukrainian Eastern Slobodian dialects, i.e. in the far east of Ukraine (in terms of current administrative divisions - the Luhansk region).

The semantic structure of oral memory texts under consideration is reflected in conceptual clusters characterised by semantic-logical features of processuality, actionality, temporality, agentivity, denotativity and axiology. These clusters include designations of phenomena and names of their referents, linked by subject relations into a comprehensive semantic complex, a nominative chain which reflects the semantic network of the text.

The author argues that in the conceptual structure of a texteme concerning historical events of the early twentieth century we can distinguish central and secondary differential features. For example, the texteme holodivka (голодівка) 'hunger, famine' is characterised by such central differential features as 'enumeration of plants that could be used as food'; 'names of dishes that could be made without flour'; 'overall assessment of the situation'; 'enumeration of events that people had to endure'; 'stories about how people survived in difficult conditions'; 'how the dead were buried'; and such secondary differential features as 'who was responsible for the famine in the country'. The components of this texteme also include reports of cannibalism, appropriation of someone else's property and accusations against people who deprived villagers of food, guarded kolkhoz property so that nothing would be taken away, etc.

These memory texts, stories in which users of dialects of the Luhansk region assess important social events of the early twentieth century, constitute one macrotext that condemns crimes against the nation - the resettlement of farmers to Siberia, coercive collectivisation, the Great Famine of 1933, alienation from anything that is Ukrainian. The evaluation of these events is mainly verbalised by means of exclamations, words expressing a strong emotional assessment. 


\title{
Cechy struktury semantycznej tekstów gwarowych dotyczących ważnych wydarzeń historycznych z początków XX wieku
}

\author{
Streszczenie
}

W artykule przeanalizowano strukturę semantyczną tekstów gwarowych dotyczących ważnych wydarzeń społecznych z początków XX wieku, opisano cechy charakterystyczne ich reprezentacji językowej oraz dynamiczne aspekty kształtowania sensu. Analizowany materiał został zebrany drogą zapisów respondentów ze starszej grupy wiekowej w latach 1990-2018 na terenach występowania ukraińskich gwar wschodniosłobodzkich, to jest na dalekim wschodzie Ukrainy (według współczesnego podziału administracyjnego w obwodzie ługańskim).

Struktura semantyczna ustnych tekstów wspomnieniowych dotyczących ważnych wydarzeń historycznych z początków XX wieku znajduje odzwierciedlenie w blokach pojęciowych, charakteryzujących się semantyczno-logicznymi cechami procesualności, akcjonalności, temporalności, agentywności, denotatywności, aksjologiczności. Są to określenia samych zjawisk oraz nazwy ogółu denotatów, powiązane relacjami przedmiotowymi w całościowy kompleks semantyczny, łańcuch nominatywny, który odzwierciedla sieć semantyczną tekstu.

Autorka dowodzi, że w strukturze pojęciowej tekstemu dotyczącego wydarzeń historycznych z początków XX wieku można wyodrębnić centralne i poboczne cechy dyferencyjne. Na przykład tekstem голодівка 'głód' charakteryzują takie centralne cechy dyferencyjne jak 'wyliczenie roślin, które można było wykorzystać jako pokarm'; 'nazwy potraw, które można było przyrządzić bez mąki'; 'ogólna ocena sytuacji'; 'wyliczenie zdarzeń, które musieli przeżyć ludzie'; 'opowiadania o sposobach przetrwania ludzi w trudnych warunkach'; 'jak chowano zmarłych' oraz poboczne cechy dyferencyjne, np. 'kto doprowadził państwo do głodu'. Wśród komponentów tekstemu występują także relacje o przypadkach kanibalizmu, wejściu w posiadanie cudzego mienia oraz oskarżenia wobec osób, które odbierały jedzenie mieszkańcom wsi, pilnowały, żeby nikt nie wziął niczego z kołchozu itp. 
Teksty wspomnieniowe, opowieści, w których użytkownicy gwar obwodu ługańskiego oceniają ważne wydarzenia społeczne z początków XX wieku, stanowią jeden makrotekst potępiający zbrodnie przeciwko narodowi przesiedlenie rolników na Syberię, przymusową kolektywizację, Wielki Głód 1933 roku, wyobcowanie od wszystkiego co ukraińskie. Podstawowymi środkami werbalizacji oceny tych wydarzeń w tekstach są wykrzykniki, słowa wyrażające zdecydowaną ocenę emocjonalną.

Keywords: dialectal text; texteme; macrotext; semantic text structure; differential trait; multidimensionality of dialectal text; explicit and implicit meaning in dialectal text

Słowa kluczowe: tekst gwarowy; tekstem; makrotekst; struktura semantyczna tekstu; cecha różnicująca; wielowymiarowość tekstu gwarowego; znaczenie dosłowne i implikowane w tekście gwarowym

\footnotetext{
Kateryna Hlukhovtseva, Luhansk Taras Shevchenko National University, Starobilsk, Ukraine ORCID: https://orcid.org/0000-0002-5581-2204

Correspondence: hlukhovtseva@gmail.com

The preparation of this article was self-financed by the author.

Competing interests: The author has declared that she has no competing interests.
} 